\title{
Prior grazing by sheep reduces waxy larkspur consumption by cattle: An observation
}

\author{
MICHAEL H. RALPHS AND JOHN D. OLSEN
}

\begin{abstract}
Authors are range scientist and veterinary medical officer, USDA/ARS, Poisonous Plant Research Laboratory, Logan, Utah 84321.
\end{abstract}

\begin{abstract}
Sheep are more resistent to larkspur polsoning than cattle. Grazing larkspur with sheep before cattle turn-in may reduce the threat of cattle poisoning. Two 2.1-ha pastures were established in Upper Ruby Valley in southwest Montana in 1987 and 1988. A band of sheep grazed 1 pasture in mid-June in both years. Sheep grazed $70 \%$ of larkspur stalks in 1987 and $35 \%$ in 1988 . Because sheep grazed little larkspur in 1988, larkspur was hand decapitated to simulate the use obtained in 1987 for the subsequent cattle grazing portion of the trial. Five cows were placed in each pasture immediately following sheep grazing in 1987 and after a 3-week delay in 1988. Cattle diets were quantified by bite counts. Waxy larkspur consumption by cattle in the sheep-grazed pasture was lower than in the cattle-only pasture expecially during and after rainstorms in 1987 and throughout the study in 1988. One cow died from larkspur poisoning in the cattle-only pasture in 1988. If sheep will graze waxy larkspur, subsequent consumption by cattle can apparently be reduced on this site, thus reducing the risk of poisoning.
\end{abstract}

Key Words: poisonous plants, biological control, Delphinium glaucescens Wats.

Larkspur (Delphinium spp.) kills more cattle on mountain rangeland than any other cause (Aldous 1917, Nielsen and Ralphs 1988). Unlike some poisonous plant problems, larkspur poisoning cannot be attributed to poor management or overgrazing. Most larkspurs are pristine species and occur on high condition rangeland. They are palatable and acutely toxic to cattle, thus management options to reduce losses are limited.

Sheep are more resistant to larkspur poisoning than are cattle (Marsh et al. 1934, Olsen 1978), and could possibly be used as a biological agent to reduce the threat of poisoning to cattle. Larkspur is generally considered good sheep forage. However, using sheep to graze larkspur has not been consistently successful in reducing cattle loss. Sheep that grazed low larkspur (Delphinium nelsonii Greene) successfully reduced the threat of poisoning to

\footnotetext{
The authors wish to thank James Israelsen and LaVon Treasure for assistance in collecting the data.

Manuscript accepted 25 July 1991.
}

cattle (Marsh et al. 1934, Taylor 1985). Aldous (1917) reported that sheep grazed immature duncecap larkspur $(D$. occidentale $\mathrm{S}$. Wats) early in the grazing season on the Mono (now Toiyabe) National Forest in Nevada and eliminated the threat to cattle. However, on the Ruby Mountains in Nevada, sheep did not graze duncecap larkspur but, through close herding, trampled it down and made it unacceptable to cattle. On the Fishlake National Forest in Utah, sheep grazed other forage in preference to tall larkspur ( $D$. barbeyi Huth), thus increasing the threat to cattle (Aldous 1917). Ralphs and Bowns (1992) reported that sheep did not consistently graze 3 species of larkspur early in the growing season. However, sheep could be compelled to increase consumption by trailing or bedding in larkspur patches.

The objectives of these studies were to determine (1) if sheep would graze waxy larkspur (Delphinium glaucescens Wats) before cattle turn-in; and (2) if this would decrease subsequent larkspur consumption by cattle.

\section{Methods}

The study was conducted in the upper Ruby River Valley $93 \mathrm{~km}$ south of Sheridan, Mont. The Upper Ruby Cattle Association graze 2,700 cows and yearlings on the allotment from June to October. Intermittent incidents of larkspur poisoning have occurred in the 3 upper pastures, the most recent of which resulted in 50 cattle deaths in 1981. This prompted a change in management to graze a band of sheep in these pastures 2 to 4 weeks before cattle turn-in (Alexander and Taylor 1986). Cattle losses to larkspur were eliminated.

The study was conducted at $2,600 \mathrm{~m}$ elevation on a flat ridge top. Habitat type was mountain big sagebrush [Artemisia tridentato var vaseyana (Rydb.) J. Boivin]-Idaho fescue (Festuca idahoensis Elmer) grassland. Idaho fescue and waxy larkspur were the most frequently encountered species throughout the pasture. Waxy larkspur density was 4 plants $/ \mathrm{m}^{2}$ and averaged 1.5 flowering stalks/plant. Silky lupine (Lupinus sericeus Pursh), and sulfur and whorled buckwheat (Eriogonum unbellatum Torr, and $E$. heracleoides Nutt) were abundant on shallow soils, and sticky gera- 
nium (Geranium viscosissimum Fisch. and Mey) and slender cinquefoil (Potentilla gracilis Dougl. ex Hook.) were abundant on deeper soils.

Two 2.1-ha pastures were enclosed with temporary electric fence in 1987 and 1988. One pasture was grazed by sheep before cattle turn-in, while the second pasture was grazed only by cattle. The sheep grazing treatment consisted of a band of 1,000 yearling ewes, which drifted through the study pasture spending a total of 1.5 hours grazing on 25 and 26 June 1987 and a total of 4 hours on 22 and $23 \mathrm{June} 1988$. Sheep did not adequately graze larkspur in 1988 , so we decapitated approximately $85 \%$ of larkspur plants in the sheep pasture by hand.

Five cows were placed in each pasture each year to compare diets. The pastures were grazed by cattle from $26 \mathrm{June}$ until $16 \mathrm{July}$ in 1987. Cattle grazing was delayed 3 weeks in 1988 and cows grazed the pastures from 8-25 July. Diets were quantified by bite count. Each cow was observed for two 5-min periods during the major morning and evening grazing periods, and the number of bites of each plant species was recorded. Species in diets were grouped into forage classes: larkspur, other forbs, and grass. Forage classes in diets were analyzed by analysis of variance (ANOVA) in a combined analysis split plot design to determine differences in larkspur intake between years, pastures, and among days. Cows within pastures were the experimental units. Years, pastures, and the year-by-pasture interaction were tested by the year-by-cowwithin pasture interaction, and the day, day-by-pasture, and 3-way interactions were tested by the residual error. Because true replication was not practical, results can not be extrapolated beyond the study area.

Larkspur use by sheep and cattle was also measured along permanent transects. Four 30-m transects were established in each pasture and 25 larkspur plants were selected and marked by a spike on each transect. Height of each stalk on each marked plant was measured before and after sheep grazing, and before and after cattle grazing to differentiate use between animal species. The number of decapitated stalks were counted and we noted whether leaves had been grazed. Since there were varying numbers of stalks per plant (1-6), we summed the total number of stalks on each transect and calculated percent of stalks grazed. Percentage of stalks grazed by cattle and reduction in height were compared between pastures and over years by ANOVA in a split-plot design with transects-within-pastures as replications. Percentage data were transformed by arcsine.

Standing crop was sampled before and after sheep grazing and before and after cattle grazing in respective pastures. A herbage capacitance meter (Neal et al. 1976) was used to estimate standing forage in 1987 from 60 plots $(30.5$ by $61 \mathrm{~cm}$ ) located at 20 -step
Table 1. Percent of larkspur stalks grazed by sheep and cattle in 1 pasture grazed by sheep followed by cattle and 1 pasture grazed only by cattle.

\begin{tabular}{llcc}
\hline & & \multicolumn{2}{c}{ Stalks grazed by: } \\
\cline { 3 - 4 } Pasture & Year & Sheep $^{1}$ & Cattle \\
\hline \multirow{3}{*}{ Sheep-Cattle } & 1987 & $70^{\mathrm{c}}$ & $60^{\mathrm{c}}$ \\
& $1988^{2}$ & $35^{\mathrm{d}}$ & $\frac{36^{\mathrm{d}}}{48^{\mathrm{b}}}$ \\
& Mean & & 84 \\
Cattle-only & 1987 & & $\frac{81}{82^{\mathrm{a}}}$ \\
& 1988 & & $\frac{84}{}$ \\
& Mean & & \\
\end{tabular}

abeans of larkspur stalks grazed by cattle followed by different letters are different $(P<0.05)$

ed Percentages of stalks grazed respectively by sheep and cattle in the sheep-cattle pasture followed by different letters differ between years $(P<0.05)$.

iData on stalks grazed by sheep was also reported in Ralphs and Bowns 1992. 2/85\% of plants outside transects were decapitated by hand following sheep grazing in 1988 to obtain the desired level of utilization for the cattle grazing study.

intervals along 2 transects running the length of the pastures. Standing crop was estimated in 1988 by clipping 20 ( 30.5 by $61 \mathrm{~cm}$ ) plots systematically placed along transects in each pasture. Samples were separated into forage classes, dried for 48 hours at $60^{\circ} \mathrm{C}$ weight, and means and standard errors calculated.

Larkspur plant parts (leaves and reproductive raceme) were harvested from several plants in the bud, flower, and pod stage of growth. Samples were air dried and analyzed for total alkaloid concentration (Manners and Ralphs 1989).

\section{Results and Discussion}

\section{Sheep Use of Larkspur}

Sheep use of larkspur differed between years $(P<0.05)$. Sheep decapitated $70 \%$ of the larkspur plants in 1987 during the 1.5 hours they grazed the pasture (Table 1). Sheep ate elongating buds and reduced the average stem height on grazed plants by $14 \mathrm{~cm}$. Sheep did not graze larkspur leaves. They grazed other forbs, principally the flowers of geranium and cinquefoil, and many small forbs and grasses were completely removed. Sheep reduced standing crop of forbs by $140 \mathrm{~kg} / \mathrm{ha}$ in 1987 , but had little effect on standing crop of grasses (Table 2).

Sheep did not graze larkspur as readily in 1988; consequently, they were held in the sheep-grazed pasture for a total of 4 hours. Still only $35 \%$ of the marked larkspur plants were grazed (Table 1). Dandelion (Taraxacum officinale Weber ex Wiggers), sulfur buckwheat, clover (Trifolium spp.), and Idaho fescue were grazed heavily, and $22 \%$ of the larkspur plants had leaves grazed. A thundershower occurred a few days prior to the sheep grazing

Table 2. Standing crop of forage classes in a pasture grazed first by sheep followed by cattle and a pasture grazed by cattle only. Standard error of the mean $( \pm)$ is presented for total standing crop in 1987 and for forage classes in 1988.

\begin{tabular}{|c|c|c|c|c|c|c|}
\hline Year & Pasture & Time & Larkspur & Forb & Grass & Total \\
\hline \multirow[t]{2}{*}{1987} & Sheep-cattle & $\begin{array}{l}\text { Before sheep } \\
\text { After sheep } \\
\text { Before cows } \\
\text { After cows }\end{array}$ & $\begin{array}{l}195 \\
135 \\
135 \\
35\end{array}$ & $\begin{array}{l}605 \\
461 \\
461 \\
256\end{array}$ & $\begin{array}{l}1362 \\
1326 \\
1326 \\
872\end{array}$ & $\begin{array}{l}2162 \pm 72 \\
1922 \pm 65 \\
1922 \pm 65 \\
1163 \pm 64\end{array}$ \\
\hline & Cattle-only & $\begin{array}{l}\text { Before cows } \\
\text { After cows }\end{array}$ & $\begin{array}{l}149 \\
0\end{array}$ & $\begin{array}{l}573 \\
527\end{array}$ & $\begin{array}{r}1400 \\
898\end{array}$ & $\begin{array}{l}2122 \pm 75 \\
1426 \pm 92\end{array}$ \\
\hline \multirow[t]{3}{*}{1988} & Sheep-cattle & $\begin{array}{l}\text { Before sheep } \\
\text { After sheep }\end{array}$ & $\begin{array}{l}190 \pm 56 \\
195 \pm 55\end{array}$ & $\begin{array}{l}622 \pm 89 \\
626 \pm 107\end{array}$ & $\begin{array}{l}775 \pm 75 \\
760 \pm 63\end{array}$ & $\begin{array}{l}1586 \pm 120 \\
1582 \pm 114\end{array}$ \\
\hline & & $\begin{array}{l}\text { Before cows } \\
\text { After cows }\end{array}$ & $\begin{array}{l}93 \pm 28 \\
28 \pm 9\end{array}$ & $\begin{array}{l}582 \pm 188 \\
298 \pm 91\end{array}$ & $\begin{array}{l}770 \pm 76 \\
708 \pm 82\end{array}$ & $\begin{array}{l}1446 \pm 165 \\
1034 \pm 129\end{array}$ \\
\hline & Cattle-only & $\begin{array}{l}\text { Before cows } \\
\text { After cows }\end{array}$ & $\begin{array}{r}165 \pm 61 \\
62 \pm 18\end{array}$ & $\begin{array}{l}817 \pm 184 \\
443 \pm 128\end{array}$ & $\begin{array}{l}822 \pm 94 \\
720 \pm 69\end{array}$ & $\begin{array}{l}1804 \pm 212 \\
1225 \pm 74\end{array}$ \\
\hline
\end{tabular}


representing the first substantial precipitation since early spring. Perhaps new growth of Idaho fescue and small forbs was more palatable than larkspur at this time. Furthermore, total alkaloid concentration in larkspur buds was higher than in 1987 (Table 3). Drought stress increases alkaloid concentration in many plants (Waller and Nowacki 1978). There may be a negative relationship between alkaloid concentration and palatability of larkspur (Ralphs and Olsen 1987, Ralphs et al. 1988). Higher alkaloid concentration in larkspur buds in 1988 may have prevented sheep from grazing them.

Table 3. Total alkaloid concentration (\% of dry matter) in waxy leafy larkspur at various phenological growth stages.

\begin{tabular}{llllll}
\hline & & & & \multicolumn{2}{c}{ Larkspur plant parts } \\
\cline { 5 - 5 } Year & Date & Growth stage & & Head & Leaf \\
\cline { 4 - 5 } 1987 & & & \multicolumn{3}{c}{$\%$} \\
\cline { 4 - 5 } & $6-27$ & Bud & 1.26 & .90 \\
& $7-7$ & Flower & 1.27 & .60 \\
& $7-16$ & Pod & 1.28 & .41 \\
& $6-25$ & Bud & 2.10 & .71 \\
& $7-11$ & Flower & 1.69 & .59 \\
& $7-29$ & Pod & 1.28 & .20 \\
\hline
\end{tabular}

Waxy larkspur apparently loses its palatability to sheep as it reaches full flower. The same band of sheep, grazing near the study site during mid-July, avoided larkspur in the full flower stage in 1987. The sheep owner reported that they are reluctant to eat waxy larkspur as it matures (Joe Helle, personal communication). Other larkspur species (tall and duncecap larkspur) become more palatable as they mature, and sheep strip the leaves off the stalks but do not select flowers or pods (Jim Bowns, personal communication; author's observations).

\section{Cattle Diets}

One cow died from larkspur poisoning in the cattle-only pasture in 1988 . She consumed larkspur flowering tops for 25 to $50 \%$ of her recorded bites on the first day and $10 \%$ of bites on day 2 . She died the second night. Average consumption of other cows in this pasture ranged from 3 to $10 \%$ of recorded bites during this time.

Cattle consumed more larkspur in the cattle-only pasture compared to the sheep-cattle pasture (Table 4). Cattle selected larkspur

Table 4. Cattle diets (\% of bites recorded) in 1 pasture grazed previously by sheep and 1 pasture grazed by cattle only.

\begin{tabular}{lcccc}
\hline \hline Pasture & Year & Larkspur & Forb & Grass \\
\hline \multirow{3}{*}{ Sheep-Cattle } & 1987 & 1.2 & 27 & 71 \\
& $\frac{1988}{\text { Mean }}$ & $\frac{0.2}{0.7^{\mathrm{b}}}$ & $\frac{9}{18^{\mathrm{a}}}$ & $\frac{90}{}$ \\
Cattle-only & 1987 & 2.1 & 26 & 72 \\
& $\underline{1988}$ & $\frac{2.7}{2.4^{\mathrm{a}}}$ & $\frac{10}{18^{\mathrm{a}}}$ & $\frac{86}{79^{\mathrm{a}}}$ \\
\hline
\end{tabular}

a,beans of forage classes followed by different letters are different $(P<0.05)$.

for an average of $2.4 \%$ of recorded bites in the cattle-only pasture compared to only $0.7 \%$ in the sheep grazed pasture when averaged over years. Cattle also consumed more of the marked larkspur plants on permanent transects in the cattle-only pasture in both years, compared to the sheep grazed pasture (Table 1).

There was a day and day-by-pasture interaction $(P<0.05)$ in both years. In 1987, peak larkspur consumption in the cattle-only pasture corresponded to precipitation events (Fig. 1). In other studies, cattle consumption of larkspur increased during precipita-
LARKSPUR IN CATTLE DIETS

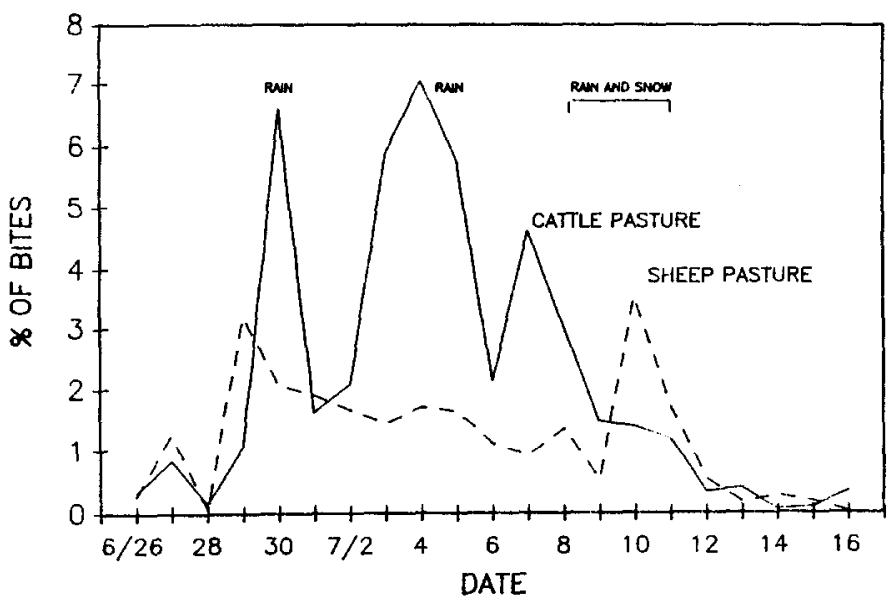

Fig. 1. 1987 trial. Larkspur in cattle diets (\% of recorded bites) in 1 pasture grazed by sheep and followed immediately by cattle, and in 1 pasture grazed by cattle only.

tion events (Pfister et al. 1988), and incidence of deaths was higher following storms than at other times (Wilcox 1988, Glover 1906, Marsh and Clawson 1916).

In 1988, larkspur consumption was highest in the cattle-only pasture during the first part of the trial and declined as larkspur was depleted (Fig. 2). After 5 days, about $50 \%$ of the larkspur plants had been defoliated, and almost all larkspur flowering heads were grazed by 9 days. Very little larkspur was consumed in the sheep-cattle pasture in 1988.

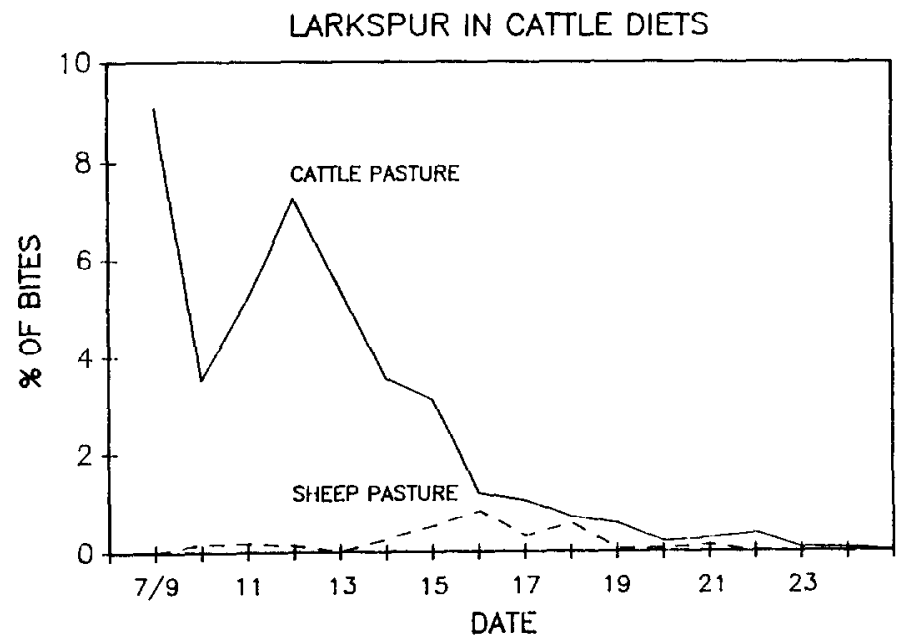

Fig. 2. 1988 trial. Larkspur in cattle diets (\% of recorded bites) in 1 pasture grazed previously by sheep and followed by cattle after 3 weeks, and in 1 pasture grazed by cattle only.

There was also a trend toward a year-by-pasture interaction $(P=$ $0.07)$. Cows in the sheep-grazed pasture consumed more larkspur in 1987 compared with 1988 (Table 4). More of the marked larkspur plants on permanent transects were also grazed by cattle in 1987 (Table 1). Some preliminary data suggested that decapitated waxy larkspur may senesce rapidly (Ralphs, unpublished data) and thus may be less acceptable to cattle. Cattle turn-in was delayed 3 weeks in 1988 to allow the decapitated larkspur plants time to senesce. Reduction of larkspur consumption in the sheep-grazed pasture in 1988 may have been due to the reduced acceptability of the remaining leaves on decapitated larkspur plants. There was no difference in cattle consumption of larkspur in the cattle-only pasture between years (Table 4), or in the percent of permanently 
marked larkspur grazed (Table 1).

Cattle preferred waxy larkspur bud and flowering racemes. They would reach out with their tongues and snap off the heads as they walked along. Prior removal of the buds by sheep may have also reduced the availability of this preferred plant part for cattle grazing afterwards.

Grasses, forbs, and total standing crop declined by $30-60 \%$ during the trials (Table 2). However, ample feed remained at the end of the trials, suggesting that grazing pressure was not a factor forcing cattle to graze larkspur. Furthermore, cattle consumption of larkspur in 1988 occurred at the beginning of the trial when grazing pressure was low.

Grass dominated cattle diets, but the proportion of grasses and forbs in their diets differed among years. Grass averaged $71 \%$ of bites in 1987 , but increased to $88 \%$ in 1988 . Forbs were higher in $1987(27 \%)$, compared to only $10 \%$ in 1988 . The smaller, succulent forbs consumed by cattle in 1987 were dried up and not available in the later grazing period in 1988 . Geranium and cinquefoil were the major forbs selected by cattle.

\section{Management Implications}

Sheep did not consistently graze waxy larkspur on this site. Sheep decapitated $70 \%$ of the larkspur heads in 1987 but only $35 \%$ in 1988. Ralphs and Bowns (1992) suggested that holding or bedding sheep on larkspur patches may increase utilization of larkspur.

If sheep will graze larkspur, subsequent consumption by cattle can likely be reduced on this site. Cattle grazed 43 to $93 \%$ less larkspur in the sheep-cattle pasture, compared to the cattle-only pasture. One cow died from larkspur poisoning in the cattle-only pasture.

Sheep did not "foul" the remaining forage for cattle. Cattle did not avoid areas grazed or feed trampled by sheep. There was only a slight reduction in standing crop of forbs from sheep grazing.

Grazing of sheep before cattle can provide mutual benefits on this site. Sheep used larkspur as a nutritious source of feed and reduced the threat of poisoning to cattle grazing afterwards. Grazing of sheep and cattle on the same range may provide additional benefits by reducing selective grazing (Cook et al. 1967), improving utilization of all forage (Ruyle and Bowns 1985) and thereby increasing carrying capacity of the range (Cook 1954, Schlundt 1980).

\section{Literature Cited}

Aldous, A.E. 1917. Eradicating tall larkspur on cattle ranges in the national forests. USDA Farmers Bull. 826.

Alexander, J.D. III, and J.E. Taylor. 1986. Sheep utilization as a control method on tall larkspur infested cattle range. Abstract 241. 39th Annu. Meeting, Soc. Range Manage. Kissimmee, Fla. Feb. 9-14, 1986.

Cook, C.W. 1954. Common use of summer range by sheep and cattle. J. Range Manage. 7:10.

Cook, C.W., L.E. Harris, and M.C. Young. 1967. Botanical and nutritive content of diets of cattle and sheep under single and common use on mountain range. J. Anim. Sci. 26:1169-1174.

Glover, G.H. 1906. Larkspur and other poisonous plants. Colorado Agr. Exp. Sta. Bull. 113, p. 1-15.

Manners, G.D., and M.H. Ralphs. 1989. Capillary gas chromatography of Delphinium diterpenoid alkaloids. J. Chromatography 466:427-432.

Marsh, C.D., and A.B. Clawson. 1916. Larkspur poisoning of livestock. USDA Bull. 365.

Marsh, C.D., A.B. Clawson, and H. Marsh. 1934. Larkspur on poison weed. USDA Farmers Bull. 98 (revised 1934).

Neal, D.L., P.O. Currie, and M.J. Morris. 1976. Sampling herbaceous native vegetation with an electronic capacitance meter. J. Range Manage. 29:74-77.

Nielson, D.B., and M.H. Ralphs. 1988. Larkspur, economic considerations. p. 119-129. In: L.F. James, M.H. Ralphs, and D.B. Nielsen (eds.). The Ecology and Economic Impact of Poisonous Plant on Livestock Production. Westview Press, Boulder, Colo.

Olsen, J.D. 1978. Tall larkspur poisoning in cattle and sheep. J. Amer. Vet. Med. Assoc. 173:762.

Pfister, J.A., M.H. Ralphs, and G.D. Manners. 1988a. Cattle grazing tall larkspur (Delphinium barbeyi) on Utah mountain rangeland. J. Range Manage. 41:118-122.

Ralphs, M.H., J.E. Bowns, and G.D. Manners. 1991. Utilization of larkspur by sheep. J. Range Manage. 44:619-622.

Ralphs, M.H., and J.D. Olsen. 1987. Alkaloids and palatability of poisonous plants. p. 78-83 In: F.D. Provenza, J.T. Flinders and E.D. McArthur (eds). Proc.Symp. on Plant-Herbivore Interactions. USDA Forest Serv. Gen. Tech. Rep. INT-222.

Ralphs, M.H., J.D. Olsen, J.A. Pfister, and G.D. Manners. 1988. Plantanimal interactions in larkspur poisoning in cattle. J. Anim. Sci. 66:2334-2342.

Ruyle, G.B., and J.E. Bowns. 1985. Forage use by cattle and sheep grazing separately and together on summer range in southwestern Utah. J. Range Manage. 38:299-302.

Schlundt, A.F. 1980. Common use grazing studies on southern Utah summer range. PhD. Diss. Utah State University, Logan.

Taylor, D.L. 1985. Introducing sheep for vegetation manipulation. Abstract 105. 38th Annu. Meeting, Soc. Range Manage. Salt Lake City, Utah. Feb. 11-15.

Waller, G.R., and E.K. Nowacki. 1978. Alkaloid biology and metabolism in plants. Plenum Press, New York, p. 143-182.

Wilcox, E.V. 1899. Cattle poisoning by the tall larkspur. Montana Agr. Exp. Sta. Bull. 22, p. 45-47. 